\title{
LONG-TERM ASSESSMENT OF TEMPERATE OCTOCORAL MORTALITY PATTERNS, PROTECTED VS. UNPROTECTED AREAS
}

\author{
Rafel Coma,,${ }^{1,5}$ Emilià Pola, ${ }^{2}$ Marta Ribes, ${ }^{3}$ And Mikel Zabala ${ }^{4}$ \\ ${ }^{1}$ Centre d'Estudis Avançats de Blanes (CEAB-CSIC), Accés Cala Sant Francesc 14, E-17300, Blanes, Girona, Spain \\ 2Associació Catalana d'Entitats de Recerca, (ACER), Pg Lluís Companys 23, E-08010 Barcelona, Spain \\ ${ }^{3}$ Institut de Ciències del Mar (ICM-CSIC), Passeig Marítim de la Barceloneta 37-49, E-08003 Barcelona, Spain \\ ${ }^{4}$ Departament d'Ecologia, Universitat de Barcelona, Diagonal 645, E-08028 Barcelona, Spain
}

\begin{abstract}
Coastal marine protected areas (MPAs) are usually established with an aim to protect areas of special ecological value. However, protected areas tend to attract more tourism and associated recreational activities, thereby exposing the biota to new risks such as high diving activity. The effects of these drawbacks are still little known for low-dynamic systems such as one of the most characteristic and fragile Mediterranean communities, the coralligenous community. Mortality rates were assessed in both heavily dived and lightly dived areas to evaluate the effect of diving on the survival of the gorgonian Paramuricea clavata. The study was designed to distinguish human-induced causes from natural causes of gorgonian mortality and to provide criteria for sustainable management of protected areas. We examined total and partial mortality of adult colonies ( $>10 \mathrm{~cm}$ in height) at four locations, two each representing one of the two situations, heavily dived (MPA) and lightly dived (control), annually over a 9-yr period (1992-2000).

High levels of recreational activity did not affect the degree of injury of the colonies. On average, the proportion of live tissue of the colonies remained steady at $\sim 91 \%$. Colony death by detachment was the main source of mortality at the MPA, four times higher than death due to overgrowth. Mortality rate due to overgrowth remained constant at both areas with an average of $1.2 \% / y r$. Natural mortality rate in sites with low diving activity was estimated to be about $2.7 \% / y r$, whereas high diving activity was estimated to increase the natural mortality rate of the species by a factor of three, up to $\sim 7.4 \% / y r$. The demographic characteristics of long-lived low-turnover structural components of ecosystems makes them especially vulnerable to disturbance events. Since an increase in diving activity seems to be unavoidably brought about by the creation of any MPA, strict regulation of recreational activity must be guaranteed in areas with low-turnover communities.
\end{abstract}

Key words: conservation needs; coralligenous community; diving impacts; gorgonian mortality; human impact; marine management; mortality, natural cf. human-induced; northwestern Mediterranean; octocoral injury; Paramuricea clavata; recreation and marine protected areas.

\section{INTRODUCTION}

Coastal marine protected areas (MPA) are usually established to protect areas of special ecological value (Dayton et al. 2000, Lubchenco et al. 2003). This policy has been shown to have a favorable effect in species vulnerable to fishing (Garcia-Rubies and Zabala 1990, Bohnsack 1998, Roberts et al. 2001). However, protected areas tend to attract more tourism and associated recreational activities. For some areas, MPAs represent a substantial economic driver, and a powerful stimulus for coastal development (e.g., Dixon et al. 1993, Vogt 1997, Fenton et al. 1998). Recreational activities are also known to carry their own risks, such as passive damage due to intensive trampling (e.g., Liddle and Kay 1987, Kay and Liddle 1989, Brosnan and Crumrine 1994), anchoring (e.g., Davis 1977) or diving (e.g., Tratalos and Austin 2001, Wielgus et al. 2002). Para-

Manuscript received 9 June 2003; revised 20 December 2003; accepted 29 December 2003. Corresponding Editor: P. K. Dayton.

${ }^{5}$ E-mail: coma@ceab.csic.es doxically, what was initially meant to preserve, can have the opposite effect. Without long-term data documenting changes over time, the contribution of various causes and effects that operate in complex ecological systems can always be argued (Dayton et al. 2000).

During the last two decades the impact of recreational activities on coastal marine protected areas has been a priority for managers of tropical ecosystems see, for example, Kelleher (1981), Tilmant (1987), Rouphael and Inglis (1997), Jamelson et al. (1999), Tratalos and Austin (2001), and Zakai and Chadwick-Furman (2002). These studies mainly focus on relatively highdynamic systems such as shallow coral reefs. In contrast, there has been a general lack of knowledge about the effects of recreational activities on low-dynamic systems such as those that characterize Mediterranean MPA (Mistri and Ceccherelli 1994, Sartoretto 1996, Coma et al. 1998a, b, Garrabou 1999, Garrabou and Harmelin 2002).

The coralligenous community is one of the most characteristic Mediterranean communities and can be 
described as a low-turnover, hard bottom of biogenic origin mainly produced by the accumulation of calcareous encrusting algae growing in dim-light conditions (Ballesteros 2003). The gorgonian Paramuricea clavata (Cnidaria: Octocorallia), one of the most representative and emblematic members of the coralligenous community, inhabits mostly vertical walls in the circalittoral zone $(20-80 \mathrm{~m})$. The species forms erect arborescent colonies up to about $130 \mathrm{~cm}$ in height (Harmelin and Marinopoulos 1994). Their assemblages constitute one of the most attractive landscapes in the Mediterranean benthos and that is why recreational divers target these communities. This is a long-lived species, in which older specimens usually reach 50 years of age (Weinberg 1991, Coma et al. 1998b). The species, which mainly reproduces sexually (Coma et al. 1995), has low recruitment rates (Coma et al. 2001) and long turnover time (8-9 years, Mistri and Ceccherelli 1994, Coma et al. 1998b). In agreement with the life-history traits suggested by high longevity and low recruitment rates, extremely low rates of adult natural mortality should be expected.

Due to their clonal nature, gorgonians are able to suffer both partial (from which they may recover) and total mortality of the colonies. Gorgonian mortality, both total and partial, may be induced by natural and anthropic causes (Weinberg and Weinberg 1979, Harmelin and Marinopoulus 1994). Natural causes of total mortality include overgrowth by other organisms and detachment by severe storms (Weinberg and Weinberg 1979, Whale 1985, Yoshioka and Yoshioka 1991, Yoshioka 1994). Detachment and pollution are the two main causes of human-induced mortality. Human-induced sources of detachment include anchors, fishing apparatus, predation, and divers (Harmelin and Marinopoulus 1994). In some areas of the Mediterranean, an extraordinary increase in overgrowth of this species by epibiotic organisms has been reported (Arnoux et al. 1992). It has been suggested that pollution may be either killing gorgonians or increasing overgrowth by decreasing regeneration rate and competitive ability of the colonies with respect to the epibiotic community (Arnoux et al. 1992). In addition, mass mortality events have been reported and may be attributed either to natural causes or to human-induced difuse causes such as climate change (Cerrano et al. 2000, Perez et al. 2000, Garrabou et al. 2001, Coma and Ribes 2003).

Marine protected areas (i.e., areas protected from all extractive and destructive activities) might represent a useful tool for the management of endangered gorgonian species because they may reduce two important sources of human-induced mortality by detachment (i.e., anchors and fishing gears; Harmelin and Marinopoulus 1994). Nevertheless, most MPAs also became powerful attactors of recreational diving (Dixon et al. 1993, Vogt 1997, Fenton et al. 1998). Recreational diving may be responsible for an increase on total mortality of gorgonians because unintentionally detached colonies are commonly observed in most diving sites (i.e., detached by blows from fins and scraping). Furthermore, it is unknown whether the common observed friction of divers' fins with the gorgonian colonies can produce or facilitate injuries that pave the road for the attachment of epibionts on the colonies.

Nowadays, the impact of recreational diving is an important concern for managers involved with conservation of the $P$. clavata populations in most Mediterranean protected areas (i.e., Port-Cros National Park [P. Robert], Lavezzi Natural Reserve [P. Lejeune], Bouches de Bonifacio Natural Reserve [J. M. Culioli], Cap de Creus Marine Park [V. Riera], Medes Islands MPA [N. Muñoz], Columbretes Islands Marine Reserve [S. Revenga], Cabo de Palos Marine Reserve [S. Revenga]; managers [names given in brackets], personal communication). We conducted a study at the Medes Islands MPA (northwest Mediterranean) to examine the role of recreational diving on the survival of $P$. clavata populations in heavily visited locations. This MPA offers an excellent experimental field, as it suffers some of the heaviest pressure from recreational diving in the Mediterranean (about 70000 annual dives in only $32 \mathrm{ha}$ ). The diving management plan set up controls on all dives within the MPA after July 1992. In 1992, diving was limited to 450 dives per day at the MPA. However, a buffer period of three years was granted, so that strict enforcement only became effective as of 1996. This, along with the growing demand of diving tourism, led to a diversification of diving sites to the nearby coast, where diving clubs started to look for new sites. Buoys were installed in a number of sites that until then had only been visited by a few locals. In a further effort to provide new diving sites outside the MPA, an old 130-m-long cargo ship was sunk by the local administration in the vicinity of the MPA.

Dayton and collaborators (2000) pointed out that the high variability of marine ecosystems means that it is difficult, but all the more important, to tell apart the physical and biotic driving functions and to separate them from human impacts. They also noticed the general lack of long-term data and the need for any measure of change in a system to be grounded in a welldefined natural standard against which the measured changes can be evaluated. The purpose of our present study was to assess natural mortality rates of $P$. clavata populations and the effect of diving on the survival of the species in order to contribute to the understanding of the processes that influence the structure and dynamics of gorgonian populations in particular and of the coralligenous community in general. It was designed as a natural experiment based on a direct comparison between populations in heavily dived and lightly dived areas. The study was intended to distinguish human-induced causes from natural causes of gorgonian mortality and to provide criteria for sustainable management of the natural resources of protected areas. The demographic values estimated in this study will 
contribute to a future risk model for the $P$. clavata population.

\section{Methods \\ Selected descriptors}

The causes of gorgonian mortality, both total and partial are not easily distinguished. Partial mortality occurs after the exposure of colonies to different kinds of physical injuries (e.g., storms, predation) or after physiological decay. Small naked skeletons are rarely observed because they are either recovered by the coenenchyme or quickly colonized by epibionts. We used two descriptors to measure partial mortality: (1) the proportion of colonies with epibionts and (2) the extent of each colony surface covered by epibionts.

In all cases, total mortality of a colony appeared to be due either to detachment (by failure of the substratum or holdfast) or injury. All injury cases were due to overgrowth by epibionts. Sediment burial was never observed during the study, most probably due to the distribution of the species in vertical or subvertical (overhanging) walls. Death by overgrowth can easily be distinguished from that due to detachment because overgrowth leaves the remaining skeleton for a long time whereas detachment is a sudden process conductive to the disappearance of the whole colony. Mortality of disappeared colonies (hereafter "detachment") cannot be safely attributed either to natural (storms) or to human-induced causes. In some cases, detached colonies were located at the base of the cliff. None of them ever reattached, and they all died from substrate abrasion. Because overgrowth may favor natural detachment due to an increase current drag, in the few cases that missing colonies had been observed to have a high extent of the colony surface covered by epibionts $(>75 \%)$, overgrowth was inferred to have been the cause of mortality. We used two descriptors to measure total mortality: (1) the rate of colonies that died due to overgrowth and (2) the rate of colonies that died due to detachment.

\section{Design}

The logic of the design was that the impact of high diving visitation at the locations within the MPA should cause higher total and partial mortality rates than those expected for undisturbed populations in control locations. To examine this logic we tested four hypotheses. First, total mortality rates (i.e., detachment and overgrowth) are higher in heavily dived locations than in infrequently dived locations. Second, detachment rates are higher in heavily dived locations than in infrequently dived locations. Third, both the proportion of colonies with epibionts and the extent of each colony surface covered by epibionts are higher in heavily dived locations than in infrequently dived locations. Fourth, both the proportion of colonies with epibionts and the extent of each colony surface covered by epi-

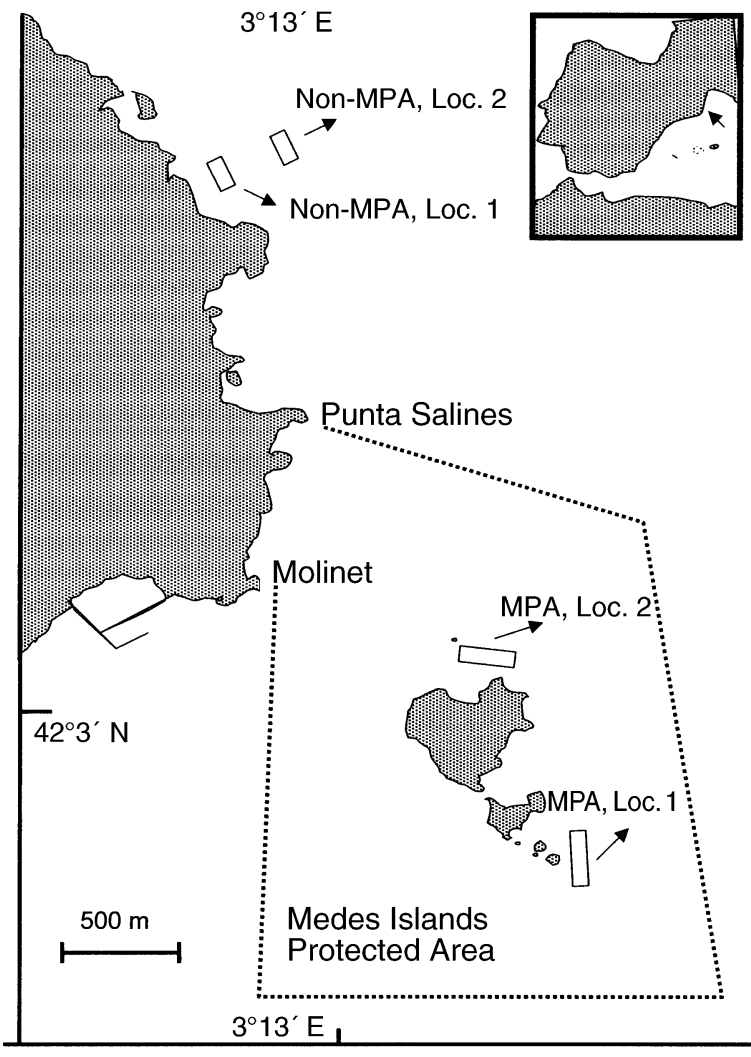

FIG. 1. Map of the northwest Mediterranean study locations within the Medes Islands marine protected area (MPA: Location 1, Tascons; Location 2, Meda Gran Nort), and outside the MPA (control: Location 1, Puig de la Sardina; Location 2, Pedra del Puig).

bionts will increase with time at the heavily dived locations.

The four parameters-i.e., detachment rates, overgrowth rates, proportion of colonies with epibionts, and extent of each colony surface covered by epibiontswere studied at four locations, two each representing one of the two experimental treatments (Fig. 1): heavily dived (Location 1 = Tascons, Location 2 = Meda Gran Nort, both within the MPA) and little dived (control; Location 1 = Puig de la Sardina, Location $2=$ Pedra del Puig, both outside the MPA). Two replicate sites were sampled within each location. All sites were located between 20 and $27 \mathrm{~m}$ depth. The number of replicate locations was limited by the scarcity of locations with little or no diving (see study locations, below). Differences between control locations need to be estimated to ascertain anthropogenic impact, since differences between control and impact locations have to be higher than those between controls (Underwood 1992).

Our study, which encompassed a nine-year period, began in 1992 and ended in 2000. No previous impact data were available because the high diving visitation in the area started long before the study. The initial 
design was to perform analyses of variance (ANOVA) with time (i.e., the sampling periods) and reserve (heavily dived locations at the reserve and lightly dived locations at the controls) as factors, and the four parameters (death rate by overgrowth, death rate by detachment, proportion of colonies with epibionts, and the extent of colony surface covered by epibionts) as variables. Location nested in reserve and site nested in location. However, due to an unpredictable change in the degree of diving visitation outside the MPA, the undisturbed control locations also became impacted locations (see Results). The control locations therefore provided an unplanned before-after, control-impact (BACI) design. The design incorporated a modification of the time factor to account for this change in visitation rate from the initial situation (i.e., the time period before and after the change in diving visitation at the control locations). Data on the four parameters were arctan transformed when normality (KolmogorovSmirnov test) and/or heterocedasticity (Levene's test) requirements were not fulfilled (Sokal and Rohlf 1995).

\section{Study locations}

The Medes Islands Marine Protected Area (MPA) is located in the northwestern Mediterranean Sea $\left(42^{\circ} 3^{\prime}\right.$ $\left.\mathrm{N}, 3^{\circ} 13^{\prime} \mathrm{E}\right)$. It was not possible to find control locations to contrast the impacted locations within the MPA, because diving activity tends to focus itself precisely on such coralligenous communities. Locations outside the MPA where the coralligenous community of Paramuricea clavata was also present and with low visitation by divers were located. Several reasons contributed to making the selected control area little visited: it was relatively inaccessible, not at all obvious, and subject to very high boat traffic, which made these locations dangerous and unattractive. These conditions allowed us to have two control, low-visited locations for three years.

\section{Diver-visitation rates}

A record was kept by the MPA management logging the number of dives at each diving location within the MPA during the whole study period. Boat patrols were conducted to determine the number of dives at the two control locations placed outside the MPA. The number of dives was assessed by visiting the locations between four and eight times per month from spring to autumn (when diving activity is more intense) and two to four times per month in winter.

\section{Survey of Paramuricea clavata populations}

At the studied sites, Paramuricea clavata is mostly located on both subvertical (overhanging) walls and north faces of large boulders. All sampled sites shared these characteristics. To determine mortality rates, every year in August we randomly laid a straight, horizontal line at a depth of 20-27 $\mathrm{m}$ and proceeded to tag the first $50 \mathrm{P}$. clavata colonies larger than $10 \mathrm{~cm}$ in maximum height that the line intercepted. Colonies were tagged around the base with a cable tie and a plastic tag provided with a correlative identification number. The color (red or yellow) and maximum height of each tagged colony was noted and they were grouped into 5-cm size classes. This arrangement (i.e., colonies tagged in a straight line, at the same depth, with correlative numbers, knowing color and maximum height) facilitated relocation of the colonies. Previous experiences with this labeling technique showed that cable ties that do not become loose within a few days can last for many years (Coma et al. 1998b). Therefore, an inspection of the labels was conducted in the weeks following the tagging process to replace the few cable ties that did become loose. Every year, the colonies from all transects were monitored. For each of the 400 colonies the following information was recorded: maximum height (in 5-cm size classes), colony condition (i.e., attached + uninjured, attached + injured, attached + dead by overgrowth, detached + dead by abrasion, detached + live fragment, disappeared/missing). From 1995 onwards the proportion of the total injured colony surface area (as in Nagelkerken et al. 1997, Harmelin et al. 1999) was noted and the nature of the epibionts was identified at the level of major taxa, except for the most abundant, which were identified to the species level. This information was always recorded by the same observer. Injury to $<5 \%$ of the colony surface was ignored. New colonies were labeled every year and the process was repeated between 1992 and 2000 at all sites.

\section{RESUlts \\ Diving}

The number of dives at both locations within the MPA (marine protected area) remained high during the whole study (Loc. 1, $5730 \pm 700$ dives/yr; Loc. 2, 5585 \pm 505 dives/yr [mean $\pm 1 \mathrm{SD}]$ ). The number of dives was always higher at the MPA locations than at the non-MPA control locations. However, diving at the control locations exhibited two clearly distinguishable time periods. From 1992 to 1995 diving at the control locations was scarce, usually about 100 dives per location and year $(108 \pm 29$ dives/yr). In 1996 diving activity increased dramatically (Fig. 2).

The growing demand of diving along with the strict enforcement of the diving limitation in 1996 appears to have been the main causes of the increase in recreational activity at our control sites (see Introduction, above).

\section{Total mortality}

There are two main reasons why a colony may detach from the basal substrate due to natural causes: (a) failure of the substratum or of the holdfast due to weakening of the substratum by boring organisms, and (b) failure of the substratum or of the holdfast due to ex- 


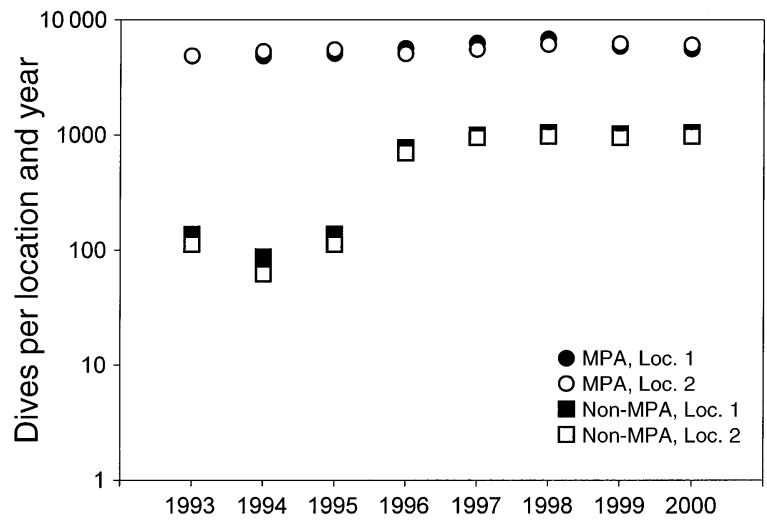

FIG. 2. Diving activity (number of dives per location and year) at the sampling locations, within and outside the MPA, between 1993 and 2000. Note the logarithmic $y$-axis scale.

cesive current drag. Many detached colonies were found at the base of the cliff. None of them exhibited failure of the holdfast indicating that most detachment had resulted from failure of the underlying substrate.

Total mortality rates of adult colonies $(>10 \mathrm{~cm}$ tall $)$ of Paramuricea clavata showed a complex temporal pattern (Figs. 3 and 4). We examined the effects of reserve (i.e., whether the studied locations were within or outside the MPA), time (i.e., 1993-1995 and 19962000), location (two in each area), and site (two in each location) on the variation on mortality rates throughout the monitoring. Location was nested in reserve and site in location (Tables 1 and 2). We observed a significant reserve and time effect on mortality rates of the species throughout the monitoring (Tables 1 and 2). Both factors accounted for most of the variation in mortality rate. For the whole studied time period, annual mortality rate was higher at the MPA than at the non-MPA (MPA, $7.26 \pm 0.82 \% / y r$, non-MPA, $5.82 \pm 0.85 \% / y r$; Table 1: Reserve effect). This difference was small due to the increase in mortality rate during the 1996-2000 time period $(1993-1995,4.11 \pm 0.65 \% / y r$ vs. $1996-$ 2000, $8.00 \pm 0.79 \% / y r$; Table 1: Time effect), which was mainly due to the increase of mortality at the nonMPA (1993-1995; $2.73 \pm 0.85 \% / y r$ vs. 1996-2000, $7.68 \pm 1.09 \% / y r$, Scheffé contrast test, Table 2).

Examining the cause of mortality (i.e., whether mortality was caused by overgrowth or by detachment) helped distinguish emerging patterns of mortality rate throughout the monitoring. Mortality due to overgrowth at the MPA and at the controls was similar (overgrowth at the MPA, $1.00 \pm 0.45 \% / y r$; overgrowth at the controls, $1.28 \pm 0.55 \% / y r$; Fig. 5). Overall mortality due to colony detachment was about 4 times higher than that due to overgrowth (detachment, $5.35 \pm$ $0.54 \% / y r$; overgrowth, $1.20 \pm 0.26 \% / y r$, Fig. 5).

The difference in mortality rates between the locations at the MPA and the control locations was mainly caused by the higher mortality rate due to detachment at the MPA (detachment at the MPA, $5.91 \pm 0.85 \%$ / yr; detachment at the controls, $3.92 \pm 0.90 \% / y r$; Fig. $5)$. The increase in mortality rate at the control locations during 1996-2000 (see above) was caused by a sharp increase in detachment mortality (1993-1995, $1.52 \pm 0.71 \% / y r, 1996-2000,6.32 \pm 1.10 \% / y r$; see Fig. 5) while mortality attributable to overgrowth remained steady over time at all locations (Fig. 5).

\section{Partial mortality}

Data on the degree of injury is presented as the proportion of live tissue of the colonies (i.e., the percentage of a colony surface area consisting of live coenenchyme) because it encompasses both the proportion of colonies with epibionts and the extent of each colony surface with epibionts in a single descriptor. Table 3 presents the data on the proportion of live tissue over the studied period (1995-2000, but not 1996), which ranged between 77.8 and $96.5 \%$ depending on the location and year. In 1996 the presence of a bloom of filamentous algae (mainly Tribonemales and Ectocarpales; E. Ballesteros, personal communication) produced large amounts of mucilage that, in sinking, covered the gorgonian colonies making observations difficult and unreliable.

Determinations at the beginning of the study showed that the proportion of colonies with epibionts did not vary with colony size $\left(r^{2}=0.062, P=0.487\right)$. The question whether previous differences between experimental conditions existed in the proportion of live tissue of the colonies was also tested at the beginning of the monitoring using ANOVA, with reserve and location as the independent variables and location and site as replicates (location nested in reserve, site nested in location). The average proportion of live tissue of the colonies $(91.41 \pm 1.45 \%$ [mean $\pm 1 \mathrm{SE}$ ] $)$ was observed to not differ among the MPA and the non-MPA area (three-way ANOVA, $F_{1,2}=0.306, P<0.636$ ),

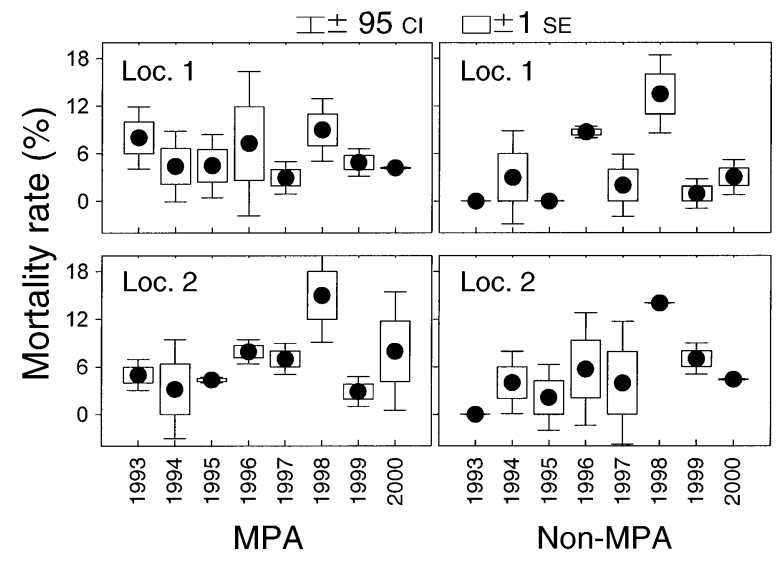

FIG. 3. Mortality rate due to detachment at the sampling locations, within and outside the marine protected area (MPA), between 1993 and 2000. Error bars are 95\% confidence intervals, and boxes indicate $\pm 1 \mathrm{SE}$ of the mean (solid circles). 


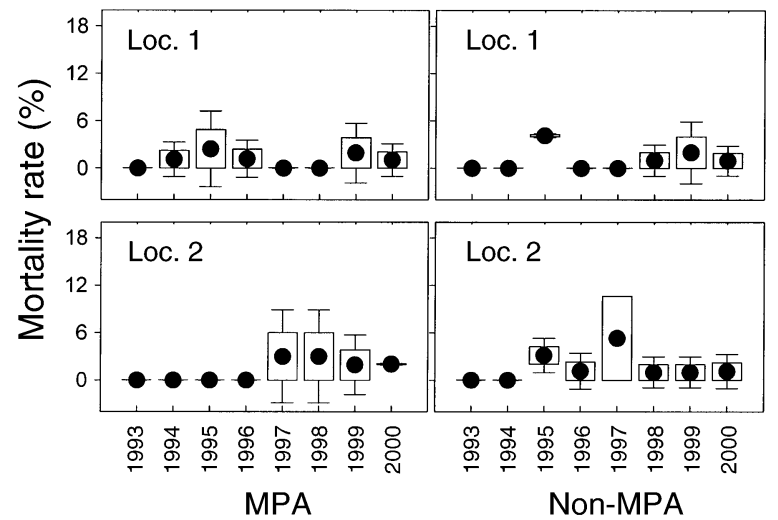

FIG. 4. Mortality rate due to overgrowth at the sampling locations, within and outside the marine protected area (MPA), between 1993 and 2000. Depiction of 1 SE and 95\% CI follows Fig. 3.

nor between the studied locations (three-way ANOVA, $\left.F_{2,4}=0.475, P<0.653\right)$.

We examined the effect of time (i.e., 1995-2000 but not 1996, see above), reserve, location, and site on the variation of the proportion of colonies with epibionts. Site was nested in location, location was nested in reserve. The proportion of colonies with epibionts remained fairly constant over the studied period (Time effect, $\left.F_{4,8}=2.728, P<0.106\right)$, at both the MPA and the non-MPA locations (Reserve effect, $F_{1,2}=0.691$, $P<0.492$ ), and so did the interaction of both factors (Time $\times$ Reserve, $F_{4,8}=2.317, P<0.145$ ). On average, for all sizes and years, $32 \pm 4.6 \%$ (mean \pm 1 $\mathrm{SE}$ ) of the colonies had some percentage of their surface colonized by epibionts.

The proportion of live tissue of the colonies for the whole sample (all sites consolidated) did not show significant variation over the studied time period, nor there was a significant interaction between time and reserve (Table 4). The analyses showed, however, a significant reserve effect. On average for the entire time period, the percentage of live tissue of the colonies decreased slightly at the MPA to about $88.66 \pm 0.76 \%$ (mean \pm $1 \mathrm{SE}$ ) (Fig. 6), while it remained constant at the NonMPA area $(\sim 92.53 \pm 0.58 \%$, main effect: Reserve, Table 4, Figs. 6 and 7). The analysis also showed a significant location effect (main effect: Location, Table 4) since on average the percentage of live tissue of the colonies decreased slightly at location 2 to about 88.82 $\pm 0.75 \%$, while it remained unchanged at location 1 . The decrease of the percentage of live tissue at the MPA did not consistently occur at both MPA locations; it was caused by the decrease seen on the colonies at location 2 in the MPA (Fig. 6). This effect was due to only one of the two studied sites (site 2) from location 2 at the MPA (Fig. 6): from 1995 to 1999 this site exhibited a clear pattern of decrease in the percentage of live tissue of the colonies with a total decrease of $18.1 \%$ in four years (from $95.9 \pm 2.4 \%$ in 1995 to 77.8 $\pm 4.3 \%$ in 1999; Fig. 6). The percentage of live tissue of the colonies did not vary over time in any of the other three locations, and remained steady at about $91.18 \pm 0.58 \%$.

\section{Discussion}

The complex temporal pattern exhibited by the mortality rates of adult colonies $(>10 \mathrm{~cm}$ tall) of Paramuricea clavata was not surprising since most ecological descriptors show complex temporal trends to which the contribution of different agents is often difficult to isolate. To approach this problem, the study was designed to include different areas, locations, and sites, and to be repeated over a nine year period.

Our study has pointed out that detachment is, indeed, the main source of mortality at the marine protected area (MPA, about 4 times higher than that due to overgrowth). This is consistent with the large number of gorgonian colonies observed at the base of the cliff at the end of summer at the MPA, few of which exhibited significant tissue injury (R. Coma and E. Pola, personal observation). However, this did not hold true for both areas (non-MPA, control, and MPA, impact) and throughout time. Whale (1985), studying the habitatrelated patterns of mortality among Jamaican gorgonians, observed that death by detachment was rare and usually restricted to the most shallow and exposed zone. Consistently, death by detachment was the main source of mortality on shallow-water gorgonians of Puerto Rico, which are fully exposed to wave action (Yoshioka and Yoshioka 1991). Several reasons suggested that, for the studied region, a high rate of death by detachment was not related to natural disturbances. First, all our locations are relatively deep $(>20 \mathrm{~m})$ whereas wave height rarely reaches over $4 \mathrm{~m}$ at the study sites (Pascual et al. 1995 and J. Pascual, unpublished data). Second, there was an increase in death by detachment at the control locations after 1996 and the rate of death by detachment became similar to that observed over the whole study period at the MPA, both situations correlating with high levels of recreational activity. Third, the storms regime of the Western Med-

TABLE 1. Results of four-way ANOVA comparing mortality rates (arctan transformed) for Paramuricea clavata among reserves (i.e., MPA and non-MPA [marine protected area]), time (i.e., 1993-1995 and 1996-2000), locations, and sites (Location nested in Reserve and Site nested in Location).

\begin{tabular}{lrcrr}
\hline \hline Source of variation & df & MS & \multicolumn{1}{c}{$F$} & \multicolumn{1}{c}{$P \dagger$} \\
\hline Reserve & 1 & 0.046 & 5.565 & 0.022 \\
Time & 1 & 0.124 & 14.915 & $<0.001$ \\
Location & 2 & 0.070 & 0.844 & 0.436 \\
Site & 4 & 0.011 & 1.237 & 0.260 \\
Reserve $\times$ Time & 1 & 0.024 & 2.883 & 0.096 \\
Time $\times$ Location & 2 & 0.015 & 1.835 & 0.171 \\
Reserve $\times$ Location & 4 & 0.005 & 0.591 & 0.671 \\
Error & 48 & 0.008 & & \\
\hline
\end{tabular}

$\dagger$ Probability values $<0.05$ have been considered significant. 
TABLE 2. Results of Scheffé's contrast test of the four-way ANOVA described in Table 1.

\begin{tabular}{lccccc}
\hline \hline & \multirow{2}{*}{ Source } & Mortality & \multicolumn{4}{c}{ Scheffé contrasts } \\
\cline { 3 - 6 } & rate & $(1)$ & $(2)$ & $(3)$ & (4) \\
\hline (1) MPA, 1993-1995 & 0.216 & & & & \\
(2) MPA, 1996-2000 & 0.267 & 0.511 & & & \\
(3) Non-MPA, 1993-1995 & 0.121 & 0.101 & 0.001 & & \\
(4) Non-MPA, 1996-2000 & 0.251 & 0.770 & 0.961 & 0.004 & \\
\hline
\end{tabular}

Note: Mortality rates in Scheffé's contrast test are arctan-transformed values. Probability values $<0.05$ have been considered significant.

iterranean, which has been particularly studied at our site (Pascual et al. 1995 and J. Pascual, unpublished data), is characterized by a concentration of heavy storms from November to May. If storms were the primary source of colony detachment the presence of colonies at the base of the cliff will be mainly observed in winter and spring. However, the presence of colonies at the base of the cliff was especially evident at the end of summer (R. Coma and E. Pola, personal observation).

Since 1996 the control location could no longer be considered representative of low levels of recreational activity. Unintentionally, the study of mortality rate at the control location became a before-after, controlimpact study of the effect of recreational activity on mortality rate and degree of injury of $P$. clavata populations. In fact, it conforms to a beyond-BACI design because it consisted of more than one sampling time before and after and more than one location per each of the two groups (control and impact, Underwood 1992). Both approaches (i.e., the comparison of populations subjected to high MPA and low, non-MPA levels of recreational activity, and the before-after, control-impact study) supported the initial hypothesis of the study that intense recreational activity results in an increase in detachment mortality rate of $P$. clavata populations. However, it did not support the hypothesis that intense recreational activity results in an increase in the degree of injury of the $P$. clavata colonies.

Causes other than recreational activity may have produced the increase in mortality observed at the control locations. However, no significant episodes of pollution occurred at the studied areas during the last decade (1990-2000, J. Pascual, personal communication). There is no evidence that predation is a regular and significant source of damage to $P$. clavata colonies, nor that its intensity may have increased (Harmelin and Marinopoulus 1994, Coma et al. 1998b, R. Coma, unpublished data). Fishing nets and lines entangled in colonies were not observed to have affected any of the studied locations. The mass-mortality event that affected sublittoral benthic communities in the Ligurian Sea in 1999 (Cerrano et al. 2000, Perez et al. 2000) did not affect the studied areas (Coma et al. 2001). Storms affected all locations similarly because they all have similar orientation and depth. Furthermore, most of these potential mortality sources, except for storms, would have implied an increase in mortality due to overgrowth and, instead, the increase in mortality at the control locations was due to detachment. Therefore, we conclude that the increase in recreational activity appears to be the main source of mortality increase at the control locations after 1996.

Recreational activity differed within and outside the MPA. Diving was the main recreational activity that affected the coralligenous community at the MPA locations, where anchoring is not allowed. At the nonMPA locations the recreational activity represented the added effect of both diving and anchoring; buoys were never installed owing to the intense boat traffic that the location sees between spring and autumn.

Our reporting that the degree of tissue injured did not vary between the control and the impacted area seems to imply that the degree of tissue injured was not significantly affected by high levels of recreational activity. This appears to be related to the gorgonian's growth strategy. Although sea fans have been documented to be the most vulnerable organisms on Caribbean coral reefs (Chadwick-Furman 1997), the kind of damage differs among growing forms (Liddle and Kay

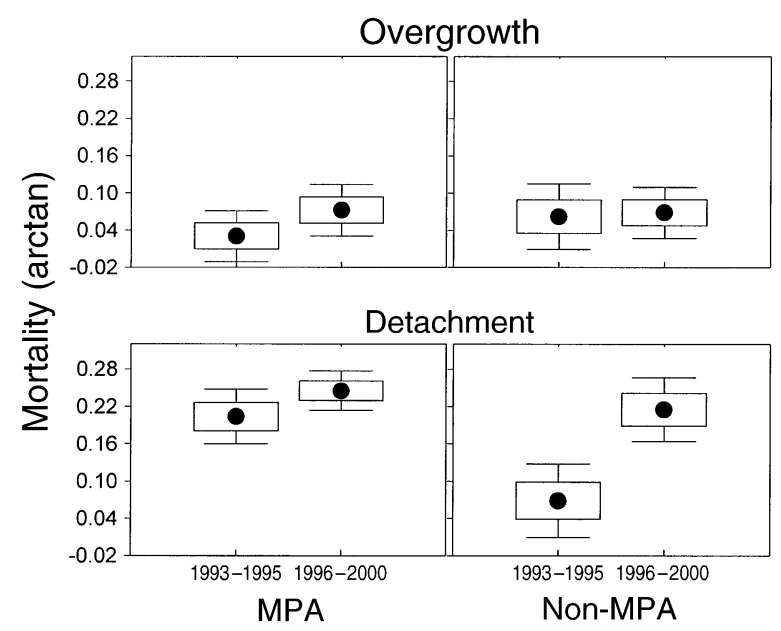

FIG. 5. Mortality rate (arctan-transformed data) due to overgrowth (top panels) and detachment (bottom panels) at the MPA and outside the MPA ("non-MPA") at two distinct time periods that are characterized by an important change in diving activity at the non-MPA (i.e., low diving activity during 1993-1995 and high diving activity during 19962000). Depiction of $1 \mathrm{SE}$ and 95\% CI follows Fig. 3. 
TABle 3. Percentage of live tissue of colonies over the years at the different studied sites within and outside the marine protected area (MPA).

\begin{tabular}{|c|c|c|c|c|c|c|c|c|c|c|}
\hline \multirow[b]{2}{*}{ Location } & \multicolumn{2}{|c|}{1995} & \multicolumn{2}{|c|}{1997} & \multicolumn{2}{|c|}{1998} & \multicolumn{2}{|c|}{1999} & \multicolumn{2}{|c|}{2000} \\
\hline & Mean & $1 \mathrm{SE}$ & Mean & $1 \mathrm{SE}$ & Mean & $1 \mathrm{SE}$ & Mean & $1 \mathrm{SE}$ & Mean & $1 \mathrm{SE}$ \\
\hline \multicolumn{11}{|l|}{ MPA } \\
\hline Loc. 1 , Site 1 & 92.1 & 3.2 & 91.9 & 2.8 & 96.3 & 1.8 & 93.7 & 2.5 & 91.7 & 3.2 \\
\hline Loc. 1 , Site 2 & 86.1 & 3.9 & 93.8 & 2.2 & 89.6 & 2.9 & 85.4 & 3.8 & 91.6 & 2.1 \\
\hline Loc. 2, Site 1 & 88.0 & 2.9 & 83.1 & 4.1 & 85.0 & 4.1 & 86.6 & 3.4 & 86.0 & 4.3 \\
\hline Loc. 2, Site 2 & 95.9 & 2.4 & 88.9 & 3.0 & 87.7 & 3.3 & 77.8 & 4.3 & 82.0 & 4.2 \\
\hline \multicolumn{11}{|l|}{ Non-MPA } \\
\hline Loc. 1 , Site 1 & 90.7 & 3.1 & 94.7 & 2.1 & 88.8 & 3.6 & 90.7 & 3.1 & 93.6 & 2.1 \\
\hline Loc. 1 , Site 2 & 94.1 & 2.1 & 96.0 & 2.0 & 96.5 & 1.3 & 94.1 & 2.1 & 93.7 & 2.4 \\
\hline Loc. 2 , Site 1 & 92.7 & 1.8 & 91.8 & 2.8 & 91.1 & 2.7 & 92.7 & 1.8 & 92.0 & 2.7 \\
\hline Loc. 2 , Site 2 & 91.7 & 3.2 & 87.1 & 3.9 & 92.8 & 2.3 & 91.7 & 3.2 & 93.7 & 2.6 \\
\hline
\end{tabular}

Note: No results are reported for 1996; see Results: Partial mortality for explanation.

1987, Hawkins and Roberts 1992, Chadwick-Furman 1997). Most of the damage produced on coral branching forms is in the form of partial colony breakage or dislodgment of the whole colony, with little injured tissue. The kind of damage that $P$. clavata received represents a variation from that usually received by branching corals because significant partial colony breakage was observed very rarely. This appears to be mainly due to the high tensile strength of the gorgonian axes (Goldberg 1976, Jeyasuria and Lewis 1987) that allows gorgonian colonies to be much more resistant than branching corals to partial colony breakage. Therefore, damage to relatively deep gorgonian colonies either from natural sources (such as storms) or from anthropogenic sources (such as anchoring and divers accidental effects of kicking, trampling, holding, grabbing, kneeling, or standing on) appears to be concentrated mainly in the form of dislodgement of the whole colony.

Our results about the percentage of colonies exhibiting some degree of injury $(32.0 \%)$ were similar to those reported for $P$. clavata population at Port Cros, France $(32.9 \%)$. The main difference between the two areas refers mainly to the observed type of injury. Injury at our study site was characterized by being mainly old injury (sensu Harmelin and Marinopoulus 1994), in which an exposed axis was fouled by sessile organisms (only in a few occasions were denuded axes observed) whereas most injured colonies at Port Cros $(86.7 \%)$ exhibited some degree of new injury (i.e., denuded axis without macroscopic fouling). Given the potential demographic consequences that variations in tissue injury may have on $P$. clavata populations, this suggests that the extent and type of injury could be considered as a potential biological indicator of disturbance events on the coralligenous community.

\section{Effect of high diving activity on natural mortality rate}

All of the above supports the hypothesis that intense diving activity results in an increased mortality by de- tachment of Paramuricea clavata populations. The pattern observed at the control area while it was little visited appears to be the pattern that provides a better estimate of the natural rates and causes of mortality of the species.

Table 5 provides an estimation of the effect of high diving activity on natural mortality rate of $P$. clavata on the basis of the data collected from both areas over the 1993-2000 time period. Mortality due to overgrowth has remained rather constant over the whole period at both areas, with an average value of $1.2 \%$ / yr. If we assume that the natural mortality rate due to detachment is that observed at the non-MPA area between 1993 and 1995 (1.5\%/yr, see above), total natural mortality rate could be estimated to be $\sim 2.7 \% / \mathrm{yr}$. In contrast, mortality rate under high diving activity could be estimated to be the addition of that due to overgrowth $(1.2 \% / y r)$ and the average of that observed at high visitation level at the MPA (1993-2000), which corresponds to $6.2 \% / y r$. This calculation estimates a mortality rate of $7.4 \% / \mathrm{yr}$ at high visitation levels, implying that high visitation levels may increase by as much as 3 times the natural mortality rate of the species.

TABLE 4. Results of four-way ANOVA comparing percentage of live tissue (arctan transformed) of Paramuricea clavata colonies over time (1995, 1997-2000), among reserve (i.e., MPA and non-MPA), location (i.e., location 1 and 2), and site (Location nested in Reserve and Site nested in Location).

\begin{tabular}{lrccc}
\hline \hline Source of variation & \multicolumn{1}{c}{ df } & MS & $F$ & $P^{\dagger}$ \\
\hline Time & 4 & 0.007 & 0.467 & 0.760 \\
Reserve & 1 & 0.150 & 9.869 & 0.002 \\
Location & 2 & 0.088 & 5.812 & 0.003 \\
Site & 4 & 0.032 & 2.082 & 0.081 \\
Time $\times$ Reserve & 4 & 0.011 & 0.732 & 0.570 \\
Time $\times$ Location & 8 & 0.023 & 1.517 & 0.146 \\
Time $\times$ Site & 16 & 0.020 & 1.333 & 0.168 \\
Error & 1934 & 0.015 & & \\
\hline
\end{tabular}

$\dagger$ Probability values $<0.05$ have been considered significant. 


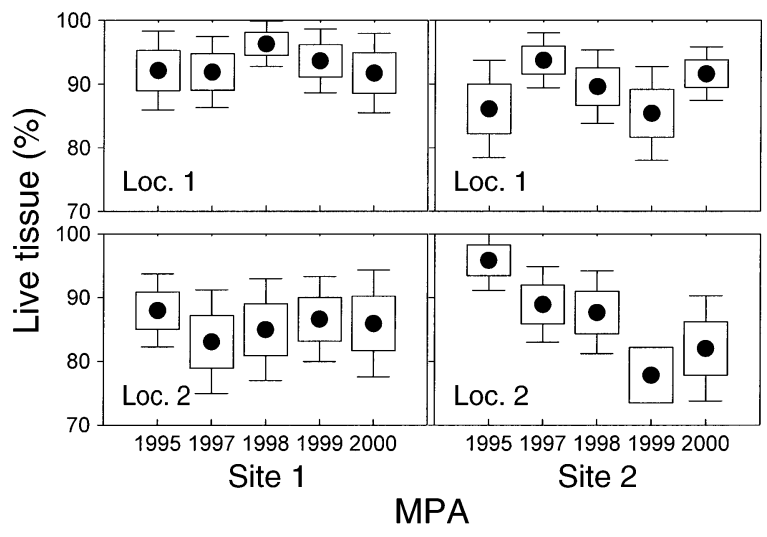

FIG. 6. Percentage of live tissue in the colonies at the different locations and sites examined within the MPA throughout the sampling period (1995-2000). Depiction of 1 SE and $95 \%$ CI follows Fig. 3.

\section{Implications of an increase in mortality rate on the population dynamics of the species}

The relevance of this result needs to be evaluated within the demographic context of the species. Mortality rates $\sim 8 \% / \mathrm{yr}$ have been observed to be relatively constant in many Caribbean gorgonian species (e.g., Yoshioka and Yoshioka 1991, Yoshioka 1994). In the deep hard-bottom gorgonians, Grigg (1988) estimated a $6 \% / y r$ rate for Corallium secundum. In the Mediterranean, Weinbauer and Velimirov (1996) estimated an average mortality rate of $17.6 \% / \mathrm{yr}$ for Eunicella $\mathrm{ca}$ volini, (ranging from $8.3 \%$ to $26.7 \% / y r$ ). However, it must be pointed out that our study covers only relatively large colonies (i.e., colonies $>10 \mathrm{~cm}$ tall) while the mortality rates discussed above refer to the whole population. Few studies allow size-related mortality rates to be distinguished. For large colonies $(>10 \mathrm{~cm}$ tall), Yoshioka (1994) estimated a mortality rate of $3.5 \% / y r$ for Pseudopterogorgia spp. and Lasker (1990) estimated 5\%/yr for Plexaura kuna colonies. The natural mortality rate of $P$. clavata, $2.7 \% / \mathrm{yr}$ is among the lowest values reported for gorgonian colonies. Only Corallium rubrum has a reported mortality rate $(1.8 \%$ / yr [Garrabou and Harmelin 2002]) lower than that of Paramuricea clavata. Recent data suggest a positive relationship between growth rate and mortality. Consistently, the lowest mortality rates have been measured in species with the lowest growth rates (see below) such as $C$. rubrum and $P$. clavata.

Growth rate of $P$. clavata has been reported to be relatively high $(2.7 \mathrm{~cm} / \mathrm{yr})$ under the strong currents of the Strait of Messina ( $>50 \mathrm{~cm} / \mathrm{s}$, Mistri and Ceccherelli 1994). In 1991, we observed a growth rate of $1.8 \mathrm{~cm} /$ $\mathrm{yr}$ at the studied area (Coma et al. 1998b). However, the analyses of the growth rate over a long-term period (1990-2000) indicate an average value of $0.8 \mathrm{~cm} / \mathrm{yr}$ (Coma et al. 2001 and R. Coma, unpublished data). This value is among the smallest reported for gorgonian species together with that of C. rubrum (Garrabou and
Harmelin 2002; see Table 5 in Coma et al. [1998b] for a review of the literature). Recruitment rate of the species is low, ranging between $2 \%$ and $12 \% / \mathrm{yr}$ with an average of 7\%/yr (Coma et al. 2001 and R. Coma, unpublished data). Furthermore, mortality of colonies $<10 \mathrm{~cm}$ tall exhibits a negative exponential function of colony size that ranges from $60 \%$ to $15 \% / \mathrm{yr}$ (Coma et al. 2001 and R. Coma, unpublished data). The colonial pattern of growth allows large colonies to escape in size (Sebens 1982, Yoshioka 1994) from many sources of mortality such as competition for space, being buried by sediment (Gotelli 1988), and the impact of predation and overgrowth by other organisms (Harvell and Suchanek 1987) that can be lethal for small colonies. A common trend of gorgonian species recruitment is that it is usually low, and that episodic events of high recruitment appear to be highly sporadic, longterm phenomena (Lasker 1990, Yoshioka 1994, Coma et al. 2001, Garrabou and Harmelin 2002), and even then high mortality rates affect small colonies. Although this is a common pattern of most species, it is especially accentuated in low-dynamic long-lived species dwelling on stable substrates (Grigg 1977). The low mortality rate of large colonies is therefore a fundamental descriptor of the demography of long-lived species (Yoshioka 1994). The low mortality rate of large colonies plays a crucial role in attenuating the effects on the population of long episodes of low recruitment and against high mortality rates of small colonies. This is why even a small increase in the mortality rate of large colonies may produce unsustainable longterm effects on the population if it is maintained over an extended time period. The demographic characteristics of long-lived species such as $P$. clavata make them especially vulnerable to disturbance events affecting large colonies.

\section{Diver carrying capacity}

"Diver carrying capacity" represents the maximum number of dives that a site can sustain without becom-

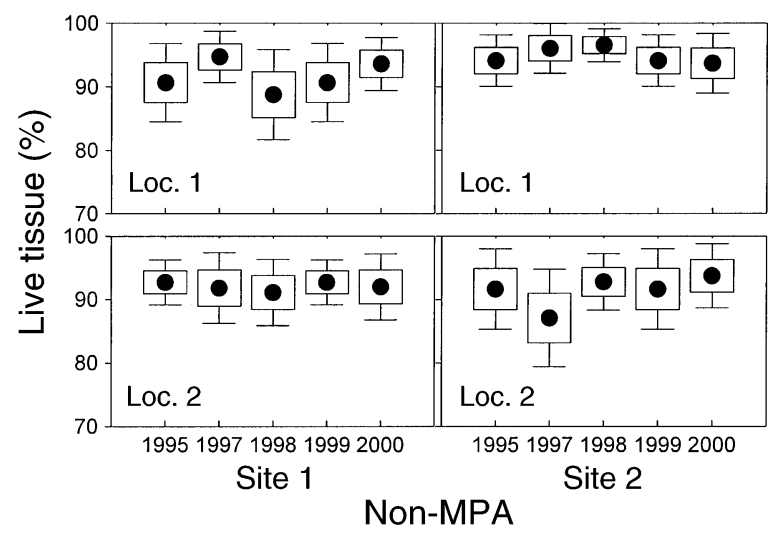

FIG. 7. Percentage of live tissue in the colonies at the different locations and sites examined outside the MPA throughout the sampling period (1995-2000). Depiction of 1 SE and 95\% CI follows Fig. 3. 
TABLE 5. Estimation of the effect of high diving activity on natural mortality rate of Paramuricea clavata on the basis of mortality data collected 1993-2000 at the Medes Islands marine protected area (MPA) and at a similarly located unprotected area in the northwest Mediterranean Sea.

\begin{tabular}{|c|c|c|c|c|c|c|}
\hline \multirow[b]{2}{*}{ Area and years $\dagger$} & \multicolumn{2}{|c|}{$\begin{array}{c}\text { Mortality cause } \\
(\% / y r)\end{array}$} & \multicolumn{2}{|c|}{ Natural mortality $(\% / y r) \neq$} & \multicolumn{2}{|c|}{$\begin{array}{c}\text { Mortality at current } \\
\text { MPA diving activity } \\
(\% / y r)\end{array}$} \\
\hline & Overgrowth & Detachment & Overgrowth & Detachment & Overgrowth & Detachment \\
\hline \multicolumn{7}{|l|}{ MPA } \\
\hline 1993-1995 & $\cdots$ & 4.9 & $\cdots$ & $\cdots$ & $\cdots$ & $\cdots$ \\
\hline $1996-2000$ & $\ldots$ & 6.9 & $\ldots$ & $\ldots$ & $\ldots$ & $\ldots$ \\
\hline 1993-2000 mean & 1.1 & 6.2 & $\cdots$ & $\cdots$ & $\cdots$ & 6.2 \\
\hline \multicolumn{7}{|l|}{ Non-MPA } \\
\hline 1993-1995 & $\ldots$ & 1.5 & $\cdots$ & 1.5 & $\ldots$ & $\ldots$ \\
\hline 1996-2000 & $\ldots$ & 6.3 & $\ldots$ & $\ldots$ & $\cdots$ & $\cdots$ \\
\hline 1993-2000 mean & 1.3 & $\cdots$ & $\cdots$ & $\cdots$ & $\cdots$ & $\cdots$ \\
\hline Mean of MPA and non-MPA & 1.2 & $\ldots$ & 1.2 & $\cdots$ & 1.2 & $\cdots$ \\
\hline Total & & & \multicolumn{2}{|c|}{2.7} & \multicolumn{2}{|c|}{7.4} \\
\hline
\end{tabular}

$\dagger$ The number of dives was always higher at MPA than non-MPA areas, but at the control (non-MPA) locations, diving activity increased dramatically in 1996 (see Fig. 2).

$\ddagger$ One can deduce "Natural mortality" by adding together that from Overgrowth, $1.2 \% / \mathrm{yr}$ (mean of MPA and non-MPA, 1993-2000), and that from Detachment at the non-MPA site before the noted increase in diving, 1.5\%/yr (1993-1995), yielding $2.7 \% / y r$. This can be compared to mortality at the current MPA diving-activity level by adding Overgrowth, $1.2 \% / y r$ (mean of MPA and non-MPA, 1993-2000), and Detachment, 6.2\%/yr (mean of 1993-1996 and 1996-2000).

ing degraded. During the last decade, diver carrying capacity has been examined for several coral-reef communities, and reported estimates range from 500 to between 10000 and 15000 dives per year and site (Hawkins and Roberts 1992, 1997, Dixon et al. 1993, Chadwick-Furman 1997, Hawkins et al. 1999, Zakai and Chadwick-Furman 2002). Hawkins and Roberts (1997) suggested a limit for carrying capacity to be between 4000 and 6000 dives per year and site, as earlier proposed by Dixon et al. (1993), on the basis of a dose-response function in which they integrated data from different coral-reef communities. Nevertheless, the discrepancies between studies indicate that diver carrying capacity appears to depend on the combination of several factors, such as the biological characteristics of the benthic system and the presence of vulnerable organisms (Harriott et al. 1997, Rouphael and Inglis 1997, Chadwick-Furman 1997), the activity pursued underwater (Rouphael and Inglis 2001), the awareness of the environmental consequences of diver action (Medio et al. 1997), the level of expertise of the divers (Davis et al. 1995), the presence of other anthropogenic stressors such as anchoring (Davis 1977, Halas 1985) and pollution (Hawkins and Roberts 1997), and the frequency of large-scale natural events that may cause far greater damage such as hurricanes (Chadwick-Furman 1997, Edmunds and Witman 1991) and mass-mortality events (Nagelkerken et al. 1997, Cerrano et al. 2000, Perez et al. 2000). In this light, with ecological variation among benthic communities world-wide, and the wide range of relative importance that many of the above-mentioned factors may exhibit, carrying-capacity figures should be considered rather elastic values (Hawkins and Roberts 1997, ChadwickFurman 1997) that need to be determined by the amount of natural damage that each benthic system is adapted to.

High visitation levels may affect not only gorgonian populations, but also the coralligenous community as a whole because gorgonian colonies are important ecosystem engineers that, together with calcareous algae, provide most of the structural complexity of the community. They provide shade and shelter that contribute to increasing the abundance and diversity of associated organisms (Wendt et al. 1985).

A function of marine protected areas is to safeguard resident flora and fauna from human activities. Within MPA the collection of animals and plants is typically prohibited, but there is normally no restriction on public access, suggesting that managers fail to recognize more subtle human impacts related to recreational activities. Even if restrictions apply, management of marine resources requires a thorough knowledge of habitats, biology, and dynamics of the involved organisms. A critical feature of any community subject to disturbances is its ability to withstand damage and to recover from it. The high dynamics of some fish taxa, for instance, seems to be behind the short-term recovery of overexploited fish populations in many MPA, an effect that has been widely publicized to support the benefits of MPA (Garcia-Rubies and Zabala 1990, Bohnsack 1998, Roberts et al. 2001). The bryozoan Pentapora fascialis, a good indicator of diving impact (Sala et al. 1996, Garrabou et al. 1998), is also, however, a highdynamic species (Cocito et al. 2001) whose populations may recover relatively quickly. However, the demo- 
graphic profile of long-lived, low-turnover structural components of ecosystems such as Paramuricea clavata makes them especially vulnerable to disturbance events.

A dramatic increase in recreational diving activity seems to follow the creation of MPAs. A clear policy about the impact of recreational activity must exist from the very beginning, very especially in areas rich with fragile, low-turnover communities such as the coralligenous community. MPAs have proven to be valid tools for environmental management; the findings and conclusions presented here should be taken as stressing the need for sound principles and practices in their dayto-day management.

\section{ACKNOWLEDGMENTS}

The authors thank the continuous encouragement and support of J. M. Gili and J. D. Ros and the helpful assistance of J. M. Llenas throughout all these years. Support for this work was provided by a "Ramón y Cajal" research contract granted to M. Ribes by the Spanish Ministry of Science and Technology. This study was funded in part by the "Direcció General de Pesca Marítima," the "Departament de Medi Natural" of the "Generalitat de Catalunya," DGICYT grants REN2000-0633-C03-01/MAR and REN 2002-01631/MAR.

\section{Literature Cited}

Arnoux, M., J. G. Harmelin, J. L. Monod, L. A. Romaña, and H. Zibrovius. 1992. Altérations des peuplements benthiques de roches profondes en Méditerranée nord-occidentale: quelques aspects biologiques et molysmologiques. Comptes Rendus de l'Académie des Sciences Serie III 314: 219-225.

Ballesteros, E. 2003. Le coralligène en Méditerranée: définition de la biocénose coralligenè, de ses principaux "constructeurs," de sa richesse et de son rôle en écologie benthique, et analyse des principales menaces. Plan d'Action stratégique pour la conservation de la biodiversité dans la Région Méditerraneénnee. Regional Activity Center for Specially Protected Areas, Tunis, Tunisia.

Bohnsack, B. L. 1998. Application of marine reserves to reef fisheries management. Australian Journal of Ecology 23: 298-304.

Brosnan, D. M., and L. L. Crumrine. 1994. Effects of human trampling on biodiversity of rocky shores communities. Journal of Experimental Marine Biology and Ecology 177: 79-97.

Cerrano, C., G. Bavestrello, C. N. Bianchi, R. Cattaneo-Vietti, B. Simone, C. Morganti, C. Morri, P. Picco, G. Sara, S. Schiaparelli, A. Siccardi, and F. Sponga. 2000. A catastrophic mass-mortality episode of gorgonians and other organisms in the Ligurian Sea (NW Mediterranean), summer 1999. Ecology Letters 3:284-293.

Chadwick-Furman, N. E. 1997. Effects of SCUBA diving on coral reef invertebrates in the U.S. Virgin Islands: implications for the management of diving tourism. Pages 91100 in J. C. Hartog, editor. Proceedings of the 6th International Conference on Coelenterate Biology. Natural History Museum, Leiden, The Netherlands.

Cocito, S., S. Sgorbini, and F. Ferdeghini. 2001. Seasonal and interannual growth variability of a bryozoan bioconstructor. Archivio di Oceanografia e Limnologia 22:155158.

Coma, R., C. Linares, E. Pola, and M. Zabala. 2001. Seguiment temporal de la gorgònia Paramuricea clavata de les illes Medes. Exercici 2001. Pages 59-82 in M. Zabala, editor. Seguiment temporal de l'àrea marina protegida de les illes Medes. Informe anual any 2001. Departament de Medi ambient, Generalitat de Catalunya. Barcelona, Spain. Coma, R., and M. Ribes. 2003. Seasonal energetic constraints in Mediterranean benthic suspension feeders: effects at different levels of ecological organization. Oikos 101:205215.

Coma, R., M. Ribes, J. M. Gili, and M. Zabala 1998a. An energetic approach to the study of life-history traits of two modular colonial benthic invertebrates. Marine Ecology Progress Series 162:89-103.

Coma, R., M. Ribes, M. Zabala, and J. M. Gili. 1995. Reproduction and cycle of gonadal development in the Mediterranean gorgonian Paramuricea clavata. Marine Ecology Progress Series 117:173-183.

Coma, R., M. Ribes, M. Zabala, and J. M. Gili. 1998 b. Growth in a modular colonial marine invertebrate. Estuarine, Coastal and Shelf Science 47:459-470.

Davis, D., V. Harriot, C. MacNamara, L. Roberts, and S. Austin. 1995. Conflicts in a marine protected area: scuba divers, economics and management in Julian Rocks Aquatic Reserve. Australian Parks and Recreation 3:29-35.

Davis, G. E. 1977. Anchor damage to coral reef on the coast of Florida. Biological Conservation 11:29-34.

Dayton, P. K., E. Sala, M. J. Tegner, and S. Thrush. 2000. Marine reserves: parks, baselines, and fishery enhancement. Bulletin of Marine Sciences 66:617-634.

Dixon, J. A., L. F. Scura, and T. van't Hof. 1993. Meeting ecological and economic goals: marine parks in the Caribbean. Ambio 22:117-125.

Edmunds, P. J., and J. D. Witman. 1991. Effect of Hurricane Hugo on the primary framework of a reef along the south shore of St. Johns, US Virgin Islands. Marine Ecology Progress Series 78:201-204.

Fenton, D. M., M. Young, and V. Y. Johnson. 1998. Representing the Great Barrier Reef to tourists: implications for tourist experience and evaluation of coral reef environments. Leisure Sciences 20:177-192.

Garcia Rubies, A., and M. Zabala. 1990. Effects of total fishing prohibition on the rocky fish assemblages of Medes Islands marine reserve (NW Mediterranean). Scientia Marina 54:317-328.

Garrabou, J. 1999. Life history traits of two Mediterranean coelenterates: Alcyonium acaule and Parazoanthus axinallae, with emphasis on growth. Marine Ecology Progress Series 178: 193-204.

Garrabou, J., and J. G. Harmelin. 2002. A 20-year study on life-history traits of a harvested long-lived temperate coral in the NW Mediterranean: insights into conservation and management needs. Journal of Animal Ecology 71:966978.

Garrabou, J., T. Perez, S. Sartoretto, and J. G. Harmelin. 2001. Mass mortality in red coral Corallium rubrum populations in the Provence region (France, NW Mediterranean). Marine Ecology Progress Series 217:263-272.

Garrabou, J., E. Sala, A. Arcas, and M. Zabala. 1998. The impact of diving on rocky sublittoral communities: a case study of a bryozoan population. Conservation Biology 12: 302-312.

Goldberg, W. M. 1976. Comparative study of the chemistry and structure of Gorgonian and Antipatharian coral skeletons. Marine Biology 35:253-267.

Gotelli, N. J. 1988. Determinants of recruitment, juvenile growth, and spatial distribution of a shallow-water grogonian. Ecology 69:157-166.

Grigg, R. W. 1977. Population dynamics of two gorgonian corals. Ecology 58:278-290.

Grigg, R. W. 1988. Recruitment limitation of a deep benthic hard-bottom octocoral population in the Hawaian Islands. Marine Ecology Progress Series 45:121-126. 
Halas, J. C. 1985. A unique mooring system for reef management in the Key Largo National Marine Sanctuary. Pages 237-242 in C. Gabrie and B. Salvat, editors. Proceedings of the 5th International Coral Reef Congress. Antenne $\mathrm{Mu}-$ seum-EPHE, Moorea; French Polynesia.

Harmelin, J. G., and J. Marinopoulos. 1994. Population structure and partial mortality of the gorgonian Paramuricea clavata (Risso) in the north-western Mediterranean (France, Port-Cros Island). Marine Life 4:5-13.

Harmelin, J. G., S. Sartoretto, and P. Francour. 1999. Mise en place d'une stratégie de suivi de lichtyofaune et des peuplements de Gorgonaires de l'archipel de Riou. Contrat Ville de Marseille. Direction de 1' environnement et de Déchets \& Centre d'Océanologie de Marseille. Centre d'Océanologie de Marseille, Marseille, France.

Harriott, V., D. Davis, and S. Banks. 1997. Recreational diving and its impact in marine protected areas in Eastern Australia. Ambio 26:173-179.

Harvell, C. D., and T. H. Suchanek. 1987. Partial predation on tropical gorgonians by Cyphoma gibbosum (Gastropoda). Marine Ecology Progress Series 38:37-44.

Hawkins, J. P., and C. M. Roberts. 1992. Effects of recreational SCUBA diving on fore-reef slope communities of coral reefs. Biological Conservation 62:171-178.

Hawkins, J. P., and C. M. Roberts. 1997. Estimating the carrying capacity of coral reefs for SCUBA diving. Pages 1923-1926 in H. A. Lessios and I. G. Macintyre, editors. Proceedings of the 8th International Coral Reef Symposium. Volume 2. Smithsonian Tropical Research Institute, Balboa, Panama.

Hawkins, J. P., C. M. Roberts, T. Van't Hoff, K. deMeyer, J. Tratalos, and C. Aldam. 1999. Effects of recreational scuba diving on Caribbean coral and fish communities. Conservation Biology 13:888-897.

Jamelson, S. C., M. S. A. Ammar, E. Saadalla, H. M. Mostafa, and B. Riegl. 1999. A coral damage index and its application to diving sites in the Egyptian Red Sea. Coral Reefs 18:333-339.

Jeyasuria, P., and J. C. Lewis. 1987. Mechanical properties of the axial skeleton in gorgonians. Coral Reefs 5:213-219.

Kay, A. M., and M. J. Liddle. 1989. Impact of human trampling in different zones of a coral reef flat. Environmental Management 13:509-520.

Kelleher, G. C. 1981. Research needs for coral reef management planning. Pages 231-236 in E. G. Gomez, C. E. Birkeland, R. W. Buddemeier, R. E. Johannes, J. A. Marsh, Jr., and R. T. Tsuda, editors. Proceedings of the 4th International Coral Reef Symposium. Volume 1. Marine Sciences Center, University of the Philippines, Quezon City, Philippines.

Lasker, H. R. 1990. Clonal propagation and population dynamics of a gorgonian coral. Ecology 71:1578-1589.

Liddle, M. J., and A. M. Kay. 1987. Resistance, survival and recovery of trampled corals on the Great Barrier Reef. Biological Conservation 42:1-18.

Lubchenco, J., S. R. Palumbi, S. D. Gaines, and S. Andelman. 2003. Plugging a hole in the ocean: the emerging science of marine reserves. Ecological Applications 13(1) Supplement:3-7.

Medio, D., R. F. G. Ormond, and M. Pearson. 1997. Effect of briefings on rates of damage to corals by scuba divers. Biological Conservation 79:91-95.

Mistri, M., and V. U. Ceccherelli. 1994. Growth and secondary production of the Mediterranean gorgonian Paramuricea clavata. Marine Ecology Progress Series 103:291296.

Nagelkerken, I., K. Buchan, G. W. Smith, K. Bonair, P. Bush, J. Garzón-Ferreira, L. Botero, P. Gayle, C. D. Harvell, C. Heberer, K. Kim, C. Petrovic, L. Pors, and P. M. Yoshioka. 1997. Widespread disease in Caribbean sea fans. II. Pat- terns of infection and tissue loss. Marine Ecology Progress Series 160:255-263.

Pascual, J., J. Salat, and M. Palau. 1995. Evolution de la température de la mer entre 1973 et 1994, près de la côte catalane. Pages 23-28 in Actas du coloque scientifique OKEANOS 95. La Méditerranée, variabilités climatiques, environnement et biodiversité. Maison de l'environnement, Montpellier, France.

Perez, T., J. Garrabou, S. Sartoretto, J. G. Harmelin, P. Francour, and J. Vacelet. 2000. Mortalité massive d'invertébrés marins: un événement sans précédent en Méditerranée nord-occidentale. Comptes Rendus de 1'Académie des Sciences Serie III 323:853-865.

Roberts, C. M., J. A. Bohnsack, F. Gell, J. P. Hawkins, and R. Goodridge. 2001. Effects of marine reserves onadjacent fisheries. Science 294:1920-1923.

Rouphael, A. B., and G. J. Inglis. 1997. Impacts of recreational scuba diving at sites with different reef topographies. Biological Conservation 82:329-336.

Rouphael, A. B., and G. J. Inglis. 2001. "Take only photographs and leave only footprints"?: an experimental study of the impacts of underwater photographers on coral reef dive sites. Biological Conservation 100:281-287.

Sala, E., J. Garrabou, and M. Zabala. 1996. Effects of diver frequentation on Mediterranean sublittoral populations of the bryozoan Pentapora fascialis. Marine Biology 126: 451-459.

Sartoretto, S. 1996. Vitesse de croissance et bioérosion des concrétionnements "coralligènes" de Méditerranée nordoccidentale. Rapport avec les variations Holocènes du niveau marin. Thèse Doctorat d'Écologie. Université d'AixMarseille II, Marseille, France.

Sebens, K. P. 1982. Competition for space: growth rate, reproductive output, and escape in size. American Naturalist 120: $189-197$.

Sokal, R., and F. J. Rohlf. 1995. Biometry. The principles and practice of statistics in biological research. Third edition. Freeman, New York, New York, USA.

Tilmant, J. T. 1987. Impacts of recreational activities on coral reefs. Pages 195-214 in B. Salvat, editor. Human impacts on coral reefs: facts and recommendations. Antenne $\mathrm{Mu}-$ seum-EPHE, Moorea, French Polynesia.

Tratalos, J. A., and T. J. Austin. 2001. Impacts of recreational SCUBA diving on coral communities of the Caribbean island of Grand Cayman. Biological Conservation 102:6775.

Underwood, A. J. 1992. Beyond BACI: the detection of environmental impacts on populations in the real, but variable, world. Journal of Experimental Marine Biology and Ecology 161:145-178.

Vogt, H. 1997. The economic benefits of tourism in the marine reserve of Apo Island, Philippines. Pages 2101-2104 in H. A. Lessios and I. G. Macintyre, editors. Proceedings of the 8th International Coral Reef Symposium. Volume 2. Smithsonian Tropical Research Institute, Balboa, Panama.

Weinbauer, M. G., and B. Velimirov. 1996. Population dynamics and overgrowth of the sea fan Eunicella cavolini (Coelenterata: Octocorallia). Estuarine, Coastal and Shelf Science 42:583-595.

Weinberg, S. 1991. Faut-il proteger les gorgones de Méditerranée? Pages 47-52 in C. F. Boudouresque, M. Avonb, and V. Gravez, editors. Les Espèces à Protéger en Méditerranée. GIS Posidonie Publications, Marseille, France.

Weinberg, S., and F. Weinberg. 1979. The life cycle of a gorgonian: Eunicella singularis (Esper, 1794). Bijdragen tot de Dierkunde 49:16-30.

Wendt, P. H., R. F. van Dolah, and C. B. O'Rourke. 1985. A comparative study of the invertebrate macrofauna associated with seven sponge and coral species collected from 
the South Atlantic Bight. Journal of the Elisha Mitchell Science Society 101:187-203.

Whale, C. M. 1985. Habitat-related patterns of injury and mortality among Jamaican gorgonians. Bulletin of Marine Science 37:905-927.

Wielgus, J., N. E. Chadwick-Furman, Z. Dubinsky, M. Schechter, and N. Zeitouni. 2002. Dose-response modeling of recreationally important coral-reef attributes: a review and potential application to the economic valuation of damage. Coral Reefs 21:253-259.
Yoshioka, P. M. 1994. Size-specific life history pattern of shallow-water gorgonian. Journal of Experimental Marine Biology and Ecology 184:111-122.

Yoshioka, P. M., and B. B. Yoshioka. 1991. A comparison of the survivorship and growth of shallow-water gorgonian species of Puerto Rico. Marine Ecology Progress Series 69: 253-260.

Zakai, D., and N. E. Chadwick-Furman. 2002. Impacts of intensive recreational diving on reef corals at Eilat, northern Red Sea. Biological Conservation 105:179-187. 